\title{
Goazen mendira! (Let's go to the mountains!). Hill walking and Basque identity ${ }^{* *}$
}

\section{Introduction}

My Basque interlocutors have often tried to convince me that hiking in the mountains is Basques' favourite way of spending free time, especially of those Basque-speaking (euskaldunak). I remember one trip to the mountains during which my Basque companion would listen closely to every group that passed by, counting those who spoke Basque, thus wanting to prove that it is Basque speakers that prevail in the mountains.

The subject of this article is a discussion on the role of the landscape (mountains) ${ }^{1}$ and specific activity associated with it (hiking in the mountains, climbing) in the process of creating Basque identity. For this purpose, the importance of the mountains in Basque mythology and national ideology will be introduced, and the historical context of the relationship between hiking in the mountains and nationalism (e.g. mendigoxale meaning "movement") will be presented. Attention will also be paid to mountain hiking as an element of the specific Basque lifestyle. At the same time, the starting point will be to show the specificity and importance of physical activity and sport (including traditional Basque sports) in the Basque region and their role in building the Basque identity. They also constitute an important space in which national and cultural separateness is expressed. I agree with the view of Wojciech Józef Burszta, according to whom sport remains to be an area where the division into nations is clearly expressed and a space where patriotic and nationalistic attitudes are manifested. This researcher describes sport as a "cultural practice" through which the national identity is recreated (Burszta, 2013: 100-103). One of the elements of identity is often those areas of sport that are considered 'national'. The participation in specific sports practices, whether active or passive,

1 The second key element of the "Basque landscape" is the sea. Nevertheless, it is the mountains, "visible from almost every place in Basque Country", that are of special importance for this culture, both according to the Basques and external observers (Strubell, 2005: 27-28).

* Correspondence address: Instytut Archeologii i Etnologii, Wydział Historyczny, Uniwersytet Gdański, ul. Bielańska 5, 80-851 Gdańsk, Polska, e-mail: katarzyna.mirgos@ug.edu.pl.

* This text was written as part of the "Nowa rodzina baskijska? Tradycja, polityka kulturowa i nowe formy życia rodzinnego" ("New Basque family? Tradition, cultural politics and new forms of family life") project, supported by the National Science Center, Poland (project no. 2016/21/B/HS3/00045). 
is often a moment of strong identification with one's own group and culture. This situation seems to be the case in the Basque Country, where the existence and practice of 'traditional' sports and activities is an element indicating cultural diversity and specificity. Moreover, the aspect of international competition and success of the Basque team are often of great symbolic importance (due to the minority status of this group, as well as complex relations with Spain).

\section{Basque sports traditions}

Sport enthusiasts often associate the Basque Country with cycling, sometimes with surfing $^{2}$, but also with mountain and high-altitude climbing. Soccer is also a popular Basque sport. The Athletic Bilbao team is particularly important in the context of national identity, because it boasts players who are exclusively Basques.

Less known activities are those called 'traditional Basque sports' (Herri kirolak). It is an umbrella term for competitions based on strength ${ }^{3}$, or dexterity, such as stone lifting (harrijasotzea), grass cutting (sega), log chopping (aizkor), as well as involving animals in which they pull a heavy stone (if it is pulled by bulls, it is called idiprobak, by horses - zaldiprobak, by donkeys - astiprobak). They originated from traditional rural works that became an element of sporting competition, and today, undoubtedly, are considered one of the elements of Basque tradition (although in some cases they resemble the disciplines present in other groups). They are a constant element of local festivals in the Basque region and they are very popular ${ }^{4}$. They are also presented in tourist folders as an attraction and Basque 'trademark' that is worth seeing. A game called pelota is considered one of the symbols of Basque culture. It attracts many viewers and is popular among children, too, who play on local courts (it is said that there is a place to play pelota in every Basque town, even if it means that the local church wall is used for this purpose). The player can use a kind of a wooden racket, a basket or their hand only. Information about the Basque pelota dates back to the $14^{\text {th }}$ century (100 simbolos vascos, 2016: 242). Running, and especially the special race called Korrika, is also worth mentioning here. Organized every year, the run, whose route includes all seven Basque provinces ${ }^{5}$, is a symbol of Basque unity and serves to support and promote the Basque language. On the Basque coast, the local teams of rowers are of great importance and their competitions are very exciting.

2 Zarautz (in the Gipuzkoa province) is one of the Basque towns attracting surfers from around the world.

3 The concept of force (indar) is of particular importance in Basque culture. It is linked to the cult of strength, and it is present in mythology (many mythical figures are giants of supernatural strength).

${ }^{4}$ Betting on the results of the competitions is also characteristic for Basques.

${ }^{5}$ Seven provinces in Spain and France are considered Basque. Three of the four located in Spain form the Basque Autonomous Community, which is sometimes referred to as the Basque Country (forgetting about the existence of Navarra in Spain and the French Basque Country which are other regions associated with Basque culture, language and identity). 
In 1986, the Basque Federation of Basque Sports (Federación de Euskadi de Deportes Vascos) was established and the official status covers 18 disciplines (Mendizabal Elordi, Lizarraga Sainz, Manuel Fuentes Mateos, 2009: 18-59). In 2014, it was recognized as a full member by the International Tug of War International Federation. It made it possible for the athletes to compete in this discipline (tug of war - sokatira in Basque) as representatives of the Basque Country, and not, like before, as representatives of Spain, and the Basque flag started to be treated equally with the flags of other countries (100 símbolos vascos, 2016: 244-45).

At the same time, sport is not only a physical activity, but also a set of specific ideas and values, including those related to gender. The Basque institution called Emakunde ${ }^{6}$, therefore, draws attention to gender inequality as a problem in the field of sport, the fact that sport is an area of male domination (fewer women practicing sports, sporadic presence of women in traditional Basque sports) and emphasizes the need to promote the popularity of sport among girls and women (Emakunde - Instituto Vasco de la Mujer, 2012). Indeed, in the case of traditional Basque sports, the participation of women in them is described as 'anecdotal' and it indicates that their activity in this field has not been well seen for a long time now. Currently, the number of women practicing these disciplines is growing (in 2006, the Basque Federation of Traditional Sports registered 146 female players) (Mendizabal Elordi, Lizarraga Sainz, Fuentes Mateos, 2009: 23-24).

Mountains are not only a place of individual rest, but also of sport and other forms of institutionalized recreation. At the end of the $19^{\text {th }}$ century, 'tourist associations' (sociedades excursionistas) began to emerge in Spain as an organized form of visiting attractive places (Moscoso Sánchez, 2004: 10-11), responding to the trend to rest in the bosom of nature, spend one's leisuretime actively, admire the landscape. At that time, spending free time in the mountains became more and more popular in the Basque Country. They ceased to be a workplace that they used to be viewed as. In addition, the late $19^{\text {th }}$ century was a time of rapid changes associated with the loss of traditional laws (Fueros in Spanish, Foroak in Basque) that protected local autonomy, and with the process of industrialization and the influx of immigrants in the Basque region. Under the influence of these transformations, the national movement emerged, whose main ideologist was Sabino Arana. For Basque nationalists, the countryside and the mountains became a symbol of what 'the essence of Basqueness' is, and an oasis in which Basque identity and traditions survived (I will return to this aspect later in the text). Over time, the first associations of mountain trekking enthusiasts began to be established, changing this individual activity into a more social form of leisure. The name of Anchón Bandrés is often mentioned at this point, as he organized the expedition to Mount Gorbea

6 "Emakunde, the Basque Institute for Women, is an autonomous body of the Basque Government which designs, promotes, advises on, coordinates and evaluates equality policies and raises awareness within society in order to achieve the real and effective equality of women and men in the Basque Autonomous Community" (Emakunde - Instituto Vasco de la Mujer, 2012). 
in 1912 in which 145 people took part. In the following years, competitions in reaching peaks were also organized (the goal was, for example, to climb 15 different mountains in one year). Gradually, Basques became fond of expeditions into high mountains and many climbers gained international recognition. It should be emphasized that women also took part in these expeditions (Raimunda Royo was a pioneer). Climbing enthusiasts certainly know the names of Miriam García or Edurne Pasaban (Auñamendi Eusko Entziklopedia, 2018).

A special event took place on May 14, 1980. The Basque flag ikurriña was placed at the top of Mount Everest ( $\mathrm{a}$ few years earlier a previous Basque expedition tried to reach the top, but failed). This was accomplished by Martín Zabaleta, the first Basque who reached the destination (and the only one from the team that consisted of 12 climbers). This expedition was of great symbolic significance for this small nation (Alonso, 2005: 128). This was undoubtedly the case in which sport is not only a fight for the best result or the desire to overcome one's own limitations. It happens when sports competition and success in this field have special significance for political or historical reasons. And also when the sports area is one of the few where one can manifest their national identity (in this context, one can even recall the FC Barcelona team matches which turned into manifestations of 'Catalanness') (Burszta, 2013: 123-124). Here, it was significant and important that the flag on the top of Mount Everest was Basque, and not Spanish.

\section{Basque Olympus}

David J. Moscoso Sánchez stated that "the relationship between mountains and humans is as ancient as humanity itself". He referred himself not only to the physical presence of the man in the mountains, but also to the admiration people felt towards mountains and the images that were created as a result of the contact with the magnitude of mountains (Moscoso Sánchez, 2004: 7) (although some authors draw attention to the non-obviousness of the attractiveness of mountain views, as well as to various stages and evolution in the perception and 'discovery' of the landscape [Frydryczak, 2013; Balon, 2010: 2328]). As Mircea Eliade noted, many cultures have had their holy mountains, connecting the earth and the sky, and marking the centre of the world (Eliade, 2001: 121-128). Hence, a thesis appeared that "all mythologies know a holy mountain, a Greek Olympus in different variants" (Jacko, 2005: 4).

Basques believed that mountains (and especially mountain caves) are inhabited by mysterious, inhuman creatures. One can meet lords of the forest (basajaunak), witches (sorginak), or the Basque goddess Mari in them. One of the caverns in Muskii, near Ataun, was inhabited by the Lord of the Forest, while the mountain ranges near Aiawere, the home of mayas with their treasures (Aguirre Sorondo, 2002: 60-61). The mountains were also the seat of Mari, the most important goddess. Considered the main figure in Basque mythology, this female deity could take on different forms. Legends from particu- 
lar villages indicate that she was a beautiful, elegant and richly dressed lady who would sometimes cross the sky in a carriage pulled by four horses. She could also become an animal (goat, horse, bird), or a plant (for example, a tree with a feminine shape), or even a cloud or fire. The stories indicate that she used to live in the Anboto mountain for seven years and in the Murumendi mountain for another seven years. Her appearance was accompanied by certain atmospheric phenomena (e.g. storm). And the mountain cave, Mari's headquarters, was untouchable and fortified with a series of prohibitions. If one entered it, one had to leave it exactly the same way they got in (for example, with their face turned towards the inside of the cave). Mari helped people, but she could also punish them (Estornes Lasa, 1974: 57-71).

Christianity replaced the old Basque beliefs. The mountains became places where the Mother of God and religious cults (for example, St. Michael in Aralar) would appear. Today, one can come across chapels and crosses in the Basque mountains. During some holidays, religious ceremonies take place there, on mountain glades or in caves (on such occasions, for example, a sacred figure is brought up there). These celebrations are erromeriak (romerías in Spanish). According to some authors, the fact that the new religion took over places associated with old beliefs and rituals had the character of a symbolic and ideological conquest (Christianity). Erromeriak consist of several stages, from the element of a walking pilgrimage (necessary to reach the place in the mountains) through the liturgy, to celebration. They build a sense of community, but not only; some authors point out that erromeriak are one of those events that were particularly important in nationalist ideology (or nationalist religion). During the times of dictatorships (Primo de Rivera's and Franco's), they were a pretext for secret, cryptonationalist meetings, or even national rituals. They were held in isolated places that at the same time had a symbolic character - the Basque mountains (as well as the sea) were perceived as iconic elements of the Basque landscape. Erromeriak were associated with a national iconography - the mountains took on national colours during these meetings (for example, thanks to the Basque flag ikurriña brought by the participants). Such celebrations built a feeling of belonging to a nation (Homobono Martínez, 2012: 43-95).

\section{Mountains in the Basque landscape and ideology}

The landscape is not only a product of nature, but also an element of an ideological construction. In the Basque Country, the landscape played a special role for authors in the second part and at the end of the $19^{\text {th }}$ century ${ }^{7}$. Referring to the idealized picture of the Basque Country from before the era of industrialization and before the loss of local laws, the Basque landscape embodied the idyllic image of Basque life. Mountains were shown not only as a source and asylum for Basque culture, but also as a barrier protect-

7 It was not just a Basque phenomenon. An important role of the landscape is indicated, for example, in the work of the Spanish Generation 98, in particular Azorín (Ortega Cantero, 2002: 119-131). 
ing against attacks and influences of foreign groups. At the same time, Miguel de Unamuno noted that the Basque picture created at the time, similar as 'Christmas shepherds', despite the intentions of its creators, may not necessarily be considered positive. This is because they are innocent and good, but also simple (Lorenzo Arza, 2014: 75-84).

The highest Basque peak is Hiru Errege Mahaia (Table of the Three Kings) with an elevation of 2428 metres. In addition to the impressive Pyrenees, dividing the area inhabited by the Basques, there are also gentler hills, covered with green vegetation, similar to the Polish Beskidy. Basque toponymy, including the names of the Basque mountains, has various sources. In some cases, their core is the word mountain - mendi in Basque (e.g. Mendieder). There are also references to terrain properties (e.g. Gainzorrotz), waters located nearby, such as springs or rivers (e.g. Errekabeltz, Iturburu), vegetation (e.g. Aritzaga, Pagoeta) or fauna (e.g. Zaldiaran, Akerrari). Some terms are associated with people, specific activities (e.g. Olagizon, Fraiburu), even with human anatomy (e.g. Mendiburu, Iturbegieta). Sometimes they refer to saints (e.g. San Donato), although some toponyms hold the memory of ancient beliefs or mythological figures (e.g. Mairumendi, Tartaloetxea) (Mujika, 2000: 34-37).

Town residents often feel connected to 'their mountain'. My interlocutor from the province of Bizkaia mentioned the legends that his mother told him and which he told his daughter (they concerned the figure of Mari, the goddess regularly visiting the local mountain). In the living room of another of my interlocutors, a painting depicting a mountain from the family village hung in the central location. It was the mountain they used to climb with their father every Sunday. Trips to the mountains are very popular among the Basques, both among the representatives of the younger and older generation.

Houses grouped around the church, the sea somewhere on the horizon, and above all the mountains - this is a landscape that is considered to be typically Basque. Although it is true, as Bruno Camus Bergareche noticed, it has become a stereotypical image (Camus Bergareche, 2012: 142-143) and an element of national ideology. The mountains became the symbol of the Basque region, and some people saw the specificity of the Basque personality, the characteristics of the Basqueness in this mountainous landscape (Juaristi, 2013: 47-48). The hilly landscape was considered by some to be the reason why Basque people resisted invaders and why their language survived (currently, this view is rather questioned).

As I pointed out earlier, intense industrialization changed the Basque region suddenly and irreversibly (it is enough to say that in some places the number of inhabitants-immigrants who came because of new jobs actually doubled). At that time, the mountains began to be depicted as the place where 'the essence of Basque culture' was preserved. 'Real Basques' lived there, and the Basque language was preserved there (100 símbolos vascos, 2016: 90-91). That's how the mendigoxale movement was born. 


\section{Mendigoxale}

The mendigoxale or mendigoizale ("mountain admirer") is a movement characteristic for the 1920s and 1930s that was associated not only with the taste for mountain hiking or healthy lifestyle, but also with the propagation of national ideas and patriotism. In times of dictatorship and repression, it was in the mountains that one could use the Basque language freely and meet people with similar political views. Then the mountains became an "asylum for the Basque identity" and also "a witness of acts of a national nature" (100 símbolos vascos, 2016: 90-91).

At the same time, mendigoxale embodied the ideal of the Basque masculinity - physical fitness and strength, religiousness, devotion to the homeland and readiness to scarify oneself for it. This man, of course, spoke Basque. The aspect of combining the world of the city and the countryside is interesting here. Mendigoxale usually came from the city, but the movement was inspired by the life of the inhabitants of the countryside and mountains (their clothing, including the beret, as well as physical strength, honour, dignity) (Llona, 2004: 196-198). He was thus "not so much an athlete as a soldier of the Basque homeland". He was characterized by "youth, radicalism and independence views", which he spread by organizing meetings or disseminating propaganda materials (Lorenzo Espinosa, 1992: 155).

\section{Does the 'real Basque' hike in the mountains?}

The Basque lifestyle has changed over the last generations. At the same time, according to research, family and work have the greatest value for Basques (at the same time, these spheres are not easy to combine). The modern family does not resemble what was considered 'traditional Basque family' - associated with a traditional farm and multigenerational group. Changes took place under the influence of industrialization or political transformations. Today, there are many forms of family life, and acceptance for them is growing (Zallo, 2006: 58-59; 70-71). At the same time, the Basque family remains significantly entangled in the sphere of politics ${ }^{8}$. The political and cultural situation of the region means that many everyday choices have a political dimension. One of them is the choice of a specific model of education. It can be noticed that its consequence is not only learning in a chosen language (Basque or Spanish), but also assimilating specific content (affecting the child's identity) and participation in specific activities (also on sports grounds - pupils of ikastola schools get to know and take part in traditional Basque sports more often, and they identify themselves as Basques more

8 At the same time, the relationship between the concept of the family and the idea of nationalism is pointed out. Burszta notes that the nation is perceived as an "extended family, shaped in a typically patriarchal way" (Burszta, 2013: 101). 
often). Many of my interlocutors, who regularly hiked in the mountains, talked about trips to the mountains with their parents which they remembered from their childhood. Many studies indicate that the physical activity and approach to sport among children is largely influenced by the attitude and example of their parents (and that through the lifestyle of the family and everyday practices the child learns about the cultural specificity of the mother's group) (Garrido Guzmán, del Carmen Campos Mesa, Castañeda Vázquez, 2010: 173-194). Perhaps this is not only about instilling a passion for physical activity or competition, discipline and perseverance in the next generation, but also a tool for communicating values related to the sense of national identity. So, maybe the choice of the 'traditional' Basque sport or the 'traditional' Basque form of spending free time can be an element of such patriotic education. Can we say that the choice of this form of activity may also be an ideological choice at the same time? And, is this kind of activity related to the identity of family members, that is, can one put forward a hypothesis that Basque-speaking families who identify themselves with the Basque identity to a greater extent than the Spanish-speaking ones spend their free time mountain hiking? I have not found data that would confirm this fascinating claim, but the view of the relationship between Basque identity and language and love for the mountains is quite widespread. Mountains and associated activities such as climbing or hiking can be seen as matching Basque nature, Basque individualism, love of nature, endurance. And cultivating these may be a form of practicing Basque identity for some people.

Another interesting element that is worth recalling here is the specific style of wear, inspired largely by the mountain wear, which became a specific element of the manifestation of 'Basqueness'. It was every day and urban wear. Ana, who is 40 and comes from a small town in Gipuzkoa, told me that when she was a teenager this fashion was very noticeable among her friends. The main element consisted of mountain boots, a shirt with stripes or Basque words, narrow trousers, a textile headband, earrings. I remember my Basque friends who once lent me hiking shoes, adding that I would look like 'a real Basque' wearing them.

\section{Conclusions}

The question about the essence of Basque identity and discussion on what it means to be Basque have been present for a long time in the discourses of Basque ideologues, political debates, and private conversations (some joke that another equally important question concerns what is for dinner or supper; after all, it is a region of food enthusiasts). There are various elements mentioned as 'traditionally Basque', which build a sense of community, cultural separateness and self-consciousness. Sports are important in this system, and a special place is occupied by mountains and mountain activities. Basque mountains have been a kind of asylum, a place where 'one can be Basque' and also a symbol of Basque culture. They used to be imagined as the habitat of dei- 
ties and other supernatural beings, aroused both terror and fascination, and finally became a tourist attraction and space for manifesting nationalist ideas and rituals. They used to be a place of isolation, but also of the creation and celebration of national identity and community (Homobono Martínez, 2012: 43-95). Today, however, they are primarily a space for rest, contact with nature and meeting mountain lovers, regardless of their beliefs and language they use.

\section{Bibliography}

100 símbolos vascos. Identidad, cultura, nacionalismo (2016), edit. S. Pablo de, Madrid.

Aguirre Sorondo A. (2002), Tierra y gentes. 75 temas vascos, Donostia.

Alonso F. (2005), ¿Por qué luchamos los vascos?, Tafalla.

Auñamendi Eusko Entziklopedia, http://aunamendi.eusko-ikaskuntza.eus/es/ [access on: 15.11.2018].

Balon J. (2010), Atrakcyjność krajobrazu górskiego - stała czy przygodna?, "Krajobrazy rekreacyjne - kształtowanie, wykorzystanie, transformacja. Problemy Ekologii Krajobrazu”, No. 27.

Burszta W.J. (2013), Kotwice pewności. Wojny kulturowe z popnacjonalizmem w tle, Warszawa.

Camus Bergareche B. (2012), Para entender la cultura vasca, Madrid.

Eliade M. (2001), Święty obszar i sakralizacja świata, [in:] Antropologia kultury. Zagadnienia i wybór tekstów, edit. A. Mencwel, Warszawa.

Emakunde - Instituto Vasco de la Mujer (2012), La evaluación de impacto en función del género en deporte, Emakunde, http://www.emakunde.euskadi.eus/english/-/informazioa/englishabout-us/ [access on: 23.11.2018].

Estornes Lasa B. (1974), Mundua Euskal - Erriaren gogoan. El Mundo en la mente popular vasca, Donostia.

Frydryczak B. (2013), Krajobraz. Od estetyki the picturesque do doświadczenia topograficznego, Poznań.

Garrido Guzmán M.E., del Carmen Campos Mesa M., Castañeda Vázquez C. (2010), Importancia de los padres y madres en la competición deportiva de sus hijos, "Revista Fuentes", No. 10, pp. 173-194.

Homobono Martínez J.I. (2012), Dimensiones nacionalitarias de las fiestas populares: lugares, símbolos y rituals politicos en las romerías vascas, "Zainak", No. 35, pp. 43-95.

Jacko J.F. (2005), Struktura symboli wertykalnych a ich rola w komunikacji międzykulturowej i zarzadzaniu, http://dspace.uni.lodz.pl:8080/xmlui/handle/11089/2154 [access on: 16.11.2018].

Juaristi J. (2013), Historia mínima del País Vasco, Madrid.

Lorenzo Arza M. (2014), Paisaje e identidad vasca en cuatro autores finiseculares, "Sancho el Sabio", No. 37, pp. 75-102.

Lorenzo Espinosa J.M. (1992), Gudari, una pasión útil. Vida y obra de Eli Gallastegi (1892-1974), Tafalla.

Llona M. (2014), From Militia Woman to Emakume: Myths Regarding Feminity during the Civil War in the Basque Country, [in:] Memory and Cultural History of the Spanish Civil War, edit. A.G. Morcillo, Brill.

Mendizabal Elordi I., Lizarraga Sainz K., Manuel Fuentes Mateos J. (2009), Guía para la enseñanza de Herri - kirolak, Vitoria-Gasteiz.

Moscoso Sánchez D.J. (2004), El proceso de institucionalización del montañismo en España, "Acciones e Investigaciones Sociales", No. 19, pp. 5-29. 
Mujika L.M. (2000), La montaña y la toponimia, [in:] Geografía simbólica. Cultura de los espacios, edit. E. Ayerbe Echebarria, Lasarte-Oria.

Ortega Cantero N. (2002), Paisaje e identidad nacional de Azorín, "Boletín de la A.G.E.", No. 34. Strubell T. (2005), Un catala entre Bascos, Barcelona.

Zallo R. (2006), El Pueblo Vasco, hoy. Cultura, historia y sociedad en la era de la diversidad y del conocimiento, Irun.

Abstract: The aim of this article is to discuss the ideological function of mountain landscape in the Basque nationalism and the importance of sport, especially mountain sports and activities, in the process of creating, reproducing and transmitting Basque identity. It includes an outline of the history of the Basque presence in the mountains, as well as the political dimension of hiking in the mountains and conquering mountain peaks. The question of the relationship between language, identity and the lifestyle of the individual and the family is analyzed, too. The text concludes that a mountain was an important space for celebration of Basque identity and even sometimes is considered the symbol of the Basque culture. The article is based on the author's field research in the Basque Autonomous Community (observations, interviews, analysis of documents). This study advances our understanding of the nature of Basque nationalism and identity.

Keywords: sport, Basque Country, identity, mountain, landscape, ideology

Article submitted: 24.11.2018; article accepted: 30.07.2019. 